\title{
Effect of a Single Intravitreal Ranibizumab Injection on Diabetic Macular Edema in Patients Who Discontinued Treatment
}

\author{
Erhan Yumusak ${ }^{1}$, Murat Kucukevcilioglu², Kemal Örnek ${ }^{l}$, Nesrin Buyuktortop ${ }^{l}$, Nurgül Örnek ${ }^{l}$
}

\section{ABSTRACT}

Objective: To evaluate the effect of a single dose of ranibizumab in patients with diabetic macular edema who discontinued treatment.

Methods: One eye of 85 patients with diabetic macular edema who discontinued treatment after a single injection of ranibizumab was studied. Best corrected visual acuity (BCVA), intraocular pressure (IOP), central macular thickness (CMT), and optical coherence tomography imaging were evaluated retrospectively. Changes in BCVA, IOP, CMT, and their correlations with the follow-up period were statistically analyzed.

Results: At baseline, the mean BCVA was $0.26 \pm 0.20$ (Snellen equivalent [SE]) and CMT was $469.04 \pm 144.6 \mu \mathrm{m}$. After a mean period of $6.12 \pm 2.46$ months, mean BCVA was $0.316 \pm 0.23$ SE and CMT was $403.07 \pm 139.7 \mu \mathrm{m}$. There was a statistically significant increase in BCVA and decreased in CMT ( $p=0.02, p<0.01$, respectively), whereas mean IOP values did not significantly change $(p=0.24)$. There was no statistically significant correlation between the follow-up duration and BCVA or CMT ( $p=0.928$ and $p=0.992$, respectively).

Conclusions: Visual outcome and CMT thickness were still superior to those before treatment even after a single ranibizumab injection. J Clin Exp Invest 2016; 7 (2): 190-194

Key words: Diabetic macular edema, ranibizumab, single dose.

\section{Diyabetik Makula Ödeminde Tek Doz Ranibizumab Tedavisinden Sonra Tedaviyi Bırakan Hastalarda Tedavinin Etkisi}

\section{ÖZET}

Amaç: Tek doz intravitreal ranibizumab enjeksiyonu yapılıp tedaviye devam etmeyen diyabetik makula ödemi (DMÖ) olan hastalarda, Ranibizumabın etkilerinin araştıııması.

Yöntemler: DMÖ olan ve tek doz Ranibizumab tedavisinden sonra tedaviyi kesmiş 85 hastanın bir gözü çalışma kapsamına alınmıştır. En iyi düzeltilmiş görme keskinliği (EDGK), göz içi basıncı (GiB), santral makula kalınlığı (SMK) bulguları (optik koherens tomografi yardımı ile) kaydedildi. EDGK, fundus bulguları, GiB, SMK değerleri ve izlem süresi ile korelasyonları istatistiksel olarak analiz edildi.

Bulgular: Tedavi öncesinde, EDGK: ortalama 0,26 \pm 0,20 (Snellen eşdeğeri :SE) CMT: ortalama 469,04 $\pm 144,6$ mikron olarak ölçüldü. 6,12 $\pm 2,46$ ay ortalama takip süresinden sonra; EDGK 0,316 $\pm 0,23$ SE idi ve SMK 403,07 $\pm 139,7$ mikron olarak bulundu. Başlangıç değerleri ile olan farklılıklar hala istatistiksel olarak anlamlı idi $(p=0,02$ ve $p<0,01)$. GiB değerlerinde ise anlamlı bir değişiklik izlenmedi $(p>0,05)$. İlem süresi ile görme keskinliği ve SMK arasında istatistiksel olarak anlamlı ilişki bulunmadı $(p>0,05)$. Son kontrolde olguların \%29,4'ında epiretinal membran izlendi.

Sonuç: Tek doz ranibizumab enjeksiyonundan en az altı ay sonra görme keskinliği ve santral makula kalınlığı hala tedavi öncesine göre istatistiksel olarak daha anlamlı derecede daha iyi olarak bulunmuştur.

Anahtar kelimeler: Diyabetik makula ödemi, ranibizumab, tek doz

\section{INTRODUCTION}

Diabetic retinopathy (DR) is the leading cause of blindness in developed countries. In these patients, the most frequent cause of decreased vision is diabetic macular edema (DME). Depending on the severity of DR, the frequency of DME may vary. DME was

${ }^{1}$ Kırıkkale University School of Medicine, Department of Ophthalmology, Kırıkkale, Turkey

${ }^{2}$ Gulhane Military Medical Academy, Department of Ophthalmology, Ankara, Turkey

Correspondence: Erhan Yumusak,

Kırıkkale Universitesi Tıp Fakültesi Hastanesi, Kırıkkale, Turkey Email: erhanyumusak@yahoo.com

Received: 01.04.2016, Accepted: 19.04.2016

Copyright @ JCEI / Journal of Clinical and Experimental Investigations 2016, All rights reserved 
reported to be present in 3\% of cases with mild nonproliferative DR, $38 \%$ with mild-to-moderate DR, and $71 \%$ with proliferative DR $[1,2]$.

It is well known that vascular endothelial growth factor (VEGF) plays an important role in the development and progression of DME [3]. It has been shown that VEGF-A is increased in the vitreous of DME patients with prominent leakage [4]. Therefore, VEGF inhibition has been proposed as an alternative treatment for DME patients. Studies in this field have been conducted using different anti-VEGF agents such as pegaptanib sodium, bevacizumab, and ranibizumab $[5,6]$. Ranibizumab is a human monoclonal antibody which inhibits all VEGF-A isoforms. It has been shown in several randomized controlled trials that intravitreal ranibizumab injection is effective in the treatment of wet-type age-related macular degeneration [7 ].

The exact best injection treatment protocol for ranibizumab has yet to be established (monthly injection, as-needed, "treat and extend" etc.). The results of the RISE and RIDE studies have shown that ranibizumab monotherapy had a lower progression to proliferative retinopathy than the sham arm.

However, the on going nature of intravitreal therapy along with its financial implications places a strain on the patient, the health care system and the treating physician. Thus, some patients may discontinue treatment due to various causes. The aim of the present study was to investigate the effect of a single ranibizumab injection in DME patients who discontinued the treatment.

\section{METHODS}

A retrospective chart review of 85 patients with DME who discontinued treatment after a single intravitreal ranibizumab injection and returned months later for a routine control examination between 2012 and 2013 was performed. The research followed the tenets of the Declaration of Helsinki and informed consent was obtained from each patient.

The inclusion criteria were as follows: 1) one eye per patient; 2) visual acuity $\geq 20 / 400$ Snellen equivalent (SE); 3) a central macular thickness $(\mathrm{CMT}) \geq$ $250 \mu \mathrm{m}$ on optical coherence tomography (OCT); 4) no other cause of decreased vision; and 5) an $\mathrm{HbAlc}$ value $<12.5 \%$. Patients with vitreomacular adhesion or an epiretinal membrane on OCT were excluded.
Best corrected visual acuity (BCVA) on a Snellen chart was recorded in all cases before the treatment. Biomicroscopy, intraocular pressure (IOP) measurements, and dilated fundus examinations were performed. Fluorescein angiography (Canon CF-1 Digital Mydriatic Retinal Camera; Canon Inc., Tokyo, Japan) and OCT (Nidek RS-3000 OCT Advance; Nidek Co. Ltd., Gamagori, Japan) images were acquired.

Before injection, the patients were informed about possible complications and informed consent was obtained. All injections were performed in an operating room. After topical anestesia with proparacaine hydrochloride $0.5 \%$ ophthalmic solution, the eyelids were scrubbed with $10 \%$ povidone-iodine. Next, the eye lashes and conjunctiva were irrigated with $5 \%$ povidone-iodine. After sterile draping and lid speculum placement, $0.5 \mathrm{mg} / 0.05 \mathrm{~mL}$ ranibizumab (Lucentis, Genentech Inc., South San Francisco, CA, USA) was intravitreally injected into the superior-temporal quadrant $4 \mathrm{~mm}$ from the limbus in phakic eyes and $3.5 \mathrm{~mm}$ from the limbus in pseudophakic and aphakic eyes. After the injection, topical lomefloxacin $0.3 \%$ was applied four times daily for 5 days. Follow-up visits were recorded. Data related to pre- and post-injection visits were collected. The main outcome measures of the study were changes in BCVA, IOP, and CMT using OCT.

The statistical analysis was performed with SPSS statistical analysis software version 16.0 for Windows (SPSS Inc., Chicago, IL, USA). A t-test was used for continuous variables, and relations among variables were investigated with Pearson's correlation coefficient. A p value $<0.05$ was considered statistically significant.

\section{RESULTS}

The study included one eye of 85 patients who discontinued the treatment after a single dose of intravitreal ranibizumab. The descriptive data are shown in Table 1.

Visual acuity and CMT before the injection were $0.26 \pm 0.20$ (range: 0.02-0.9) SE and $469.04 \pm 144.6$ $\mu \mathrm{m}$, respectively; the corresponding values changed to $0.316 \pm 0.23 \mathrm{SE}$ and $403.07 \pm 139.7 \mu \mathrm{m}$ after injection. The differences in BCVA $(\mathrm{p}=0.02)$ and CMT $(p<0.001)$ were statistically significant when comparing pre- and post-injection visits. There were no significant differences in IOP between the pre-and postinjection measurements $(\mathrm{p}>0.05)$. 
Table 1. The descriptive data of patients

\begin{tabular}{lc}
\hline Characteristics & Values \\
\hline Age (years), mean \pm SD, range & $61.9 \pm 7.9$ (44-78) \\
Sex (female/male) & $43 / 42$ \\
Right eye/Left eye & $55 / 30$ \\
$\begin{array}{l}\text { Duration of diabetes (years), } \\
\text { mean } \pm \text { SD }\end{array}$ & $14.16 \pm 7.2(2-35)$ years \\
Follow-up duration, & \\
(months), mean \pm SD & $6.12 \pm 2.46$ (3-12) months \\
\hline
\end{tabular}

DME: diabetic macular edema; SD: standard deviation.

Table 2. Best corrected visual acuity, intraocular pressure, and central macular thickness values at baseline and after injection at last visit

\begin{tabular}{lccc}
\hline Outcome & $\begin{array}{c}\text { Baseline } \\
\text { (mean } \pm \text { SD) }\end{array}$ & $\begin{array}{c}\text { Last visit } \\
\text { (mean } \pm \text { SD) }\end{array}$ & p value \\
\hline BCVA & $0.26 \pm 0.20$ & $0.316 \pm 0.23$ & 0.025 \\
IOP & $16.46 \pm 3.12$ & $16.87 \pm 3.12$ & 0.248 \\
CMT & $469.04 \pm 144.6$ & $403.07 \pm 139.7$ & $<0.001$ \\
\hline
\end{tabular}

BCVA: best corrected visual acuity on a Snellen chart; IOP: intraocular pressure; CMT: central macular thickness on optical coherence tomography; SD: standard deviation.

Table 3. Distribution of patients according to the follow-up durations and the mean macular thickness and the best corrected visual acuities at baseline and the last visit and the number of patients with epiretinal membrane at the last visit.

\begin{tabular}{cccccccccc}
\hline $\begin{array}{l}\text { Follow-up } \\
\begin{array}{l}\text { Duration } \\
\text { (months) }\end{array}\end{array}$ & $\mathbf{n}$ & $\mathrm{CMT}_{0}$ & $\mathrm{CMT}_{1}$ & $\mathbf{p}^{*}$ & BCVA $_{0}$ & $\mathrm{BCVA}_{1}$ & $\mathbf{p}^{*}$ & $\mathrm{ERM}$ \\
\hline 3 & 16 & 518 & 451 & 0.036 & 0.30 & 0.31 & 0.556 & 1 \\
\hline 4 & 10 & 449 & 365 & 0.029 & 0.30 & 0.37 & 0.063 & 2 \\
\hline 5 & 6 & 465 & 377 & 0,046 & 0.31 & 0.27 & 0.227 & 3 \\
\hline 6 & 23 & 464 & 377 & 0.015 & 0.25 & 0.31 & 0.046 & 9 \\
\hline 7 & 9 & 453 & 396 & 0.049 & 0.18 & 0.26 & 0.037 & 3 \\
\hline 8 & 11 & 448 & 413 & 0.097 & 0.26 & 0.38 & 0.033 & 2 \\
\hline 9 & 4 & 576 & 520 & 0.068 & 0.20 & 0.30 & 0.051 & 2 \\
\hline 11 & 3 & 403 & 391 & 0.455 & 0.26 & 0.32 & 0.072 & 1 \\
\hline 12 & 4 & 509 & 495 & 0.144 & 0.26 & 0.32 & 0.070 & 2 \\
\hline
\end{tabular}

Follow-up duration: The patients are grouped according to the follow-up durations; $\mathbf{n}$ : the number of patients in each follow-up group; $\mathrm{CMT}_{0}$ : central macular thickness on optical coherence tomography at baseline; $\mathrm{CMT}_{1}$ : central macular thickness on optical coherence tomography at baseline; BCVA $_{0}$ : best corrected visual acuity on a Snellen chart at baseline; BCVA $_{1}$ : best corrected visual acuity on a Snellen chart at the last visit; ERM: the number of patients with epiretinal membrane at the last visit. * Paired T test
Pre- and post-injection BCVA, CMT, and IOP measurements are presented in Table 2.

Follow-up duration of patients after single injection: The distribution of the mean macular thickness and best corrected visual acuity of those patients at baseline and the last visit are given in Table 3 .

\section{DISCUSSION}

It has been shown that in cases of clinically significant DME, $50 \%$ of patients lost at least two lines in BCVA over 2 years, and $25 \%$ lost at least 15 letters over 3 years. In the Early Treatment Diabetic Retinopathy Study, it was found that visual loss can be reduced by up to $50 \%$ with laser photocoagulation [8].

One such VEGF inhibitor is bevacizumab, a US Food and Drug Administration-approved full-length humanized monoclonal antibody that until recently was used for the treatment of metastatic colorectal cancer.[9-10] Bevacizumab has emerged as a therapeutic strategy for retinal diseases, especially age-related macular degeneration, [11-13] providing promising functional results. It seems very reasonable to assume that VEGF inhibitors such as bevacizumab will also be applicable in other retinal diseases, such as retinal vein occlusion [14] and diabetic macular edema. Although widely used, bevacizumab has not been approved by the Food and Drug Administration yet. Currently it could be used only as a off-label drug.

A detailed analysis of Phase 3 clinical trials has generated evidence-based guide lines for using ranibizumab for the treatment of diabetic macular edema [15]. Also, there have been numerous prospective [5,6] and retrospective studies [16] evaluating the optimal dosing regimen for anti-vascular endothelial growth factor (VEGF) treatment, individualized patient outcomes are still being used in routine clinical setting. Recently, there have been several studies comparing bevacizumab with ranibizumab in the treatment of diabetic macular edema, which have shown that both drugs seem to be equally effective but both require ongoing treatment. A positive effect of ranibizumab treatment on patients' vision-related quality of life has also been reported [17].

Vaze et al. have examined the reasons for discontinuation of intravitreal therapy as these would obviously influence the long-term outcomes of intervention [18]. Treatment was discontinued in $42.3 \%$ of patients in the practice over a 6 -year period. Of those, the treatment was discontinued in $14.5 \%$ by the physician, 
in $10.5 \%$ by the patient, and in $16.1 \%$ because of other reasons. In $1.2 \%$ of patients, the cause was not found. The visual acuity of the group in which treatment was eventually deemed reduced significantly, whereas in those in whom further treatment was believed to be unnecessary improved. Surprisingly, economic burden, treatment frequency, difficulty to attend the practice, pain and discomfort, or treatment not perceived as beneficial were relatively uncommon causes of treatment discontinuation with a combined proportion of $6.0 \%$.

Muether et al. used Luminex technology (Luminex 200; Luminex Inc., Austin, TX, USA) to measure VEGF suppression in the aqueous humor, and showed that the treatment effect disappeared after 33.7 \pm 5.1 days [19]. Ikemori et al have shown that [20] a single-dose regimen can lead to equivalent functional and morphologic retinal improvement with fewer injections compared with the loading regimen in AMD patients. In the current study, visual acuity, OCT, and IOP measurements were obtained after a mean followup duration of $6.14 \pm 2.46$ months in patients with DME who received only a single ranibizumab injection and then discontinued the treatment. Muether showed that the efficacy of intravitreal ranibizumab treatment ceases after 33.7 days. However, in the current study, even after $6.14 \pm 2.46$ months, visual acuity and CMT remained significantly improved compared to preinjection levels. Certainly, this does not mean that discontinuation could be suggested. We only emphasize that even a single dose of intravitreal ranibizumab may still prevent the progression of maculopathy.

There are some studies reporting that anti-VEGF treatment improves vitreomacular interface abnormalities $[21,22]$. Interestingly, in our study epiretinal membrane occurred in $29.4 \%$ of patients at the end of 12 months. It is rather difficult to state whether epiretinal membrane development is a part of a natural process or a rebound effect due to discontinuation of treatment after a single dose.

We believe that the cause may be a decreased but still ongoing anti-edematous effect of ranibizumab or the ongoing healing effect of a single dose ranibizumab. We did not encounter any similar reports to make head-to-head comparisons. Additionally, we did not observe a correlation between CMT and followup duration. It has been shown in some studies that individual features such as HbA1c levels and the presence of inner-outer segment junction (IS/OS) damage may affect treatment response and the timing of re- peated injections $[23,24]$. We believe that these factors may have influenced the results obtained in the current study. Because the mean best corrected visual acuity and macular thickness values were better than the baseline in each follow-up group including the patients with a follow-up period of 3 months and even 12 months, it may be thought that some of the ameliorating effects of ranibizumab may be lasting. The major limitation of our study was to consist entirely uncontrolled patients. But due to ethical reasons we could not able to perform like this study under the controlled conditions.

In conclusion, visual outcome and CMT thickness were still superior to those before treatment even after a single ranibizumab injection. In this study, we made some rough assumptions about the discontinued ranibizumab in DME patients. Surely, further studies are needed to investigate the possible ongoing effect of a single injection of intravitreal ranibizumab.

Declaration of Conflicting Interests: The authors declare that they have no conflict of interest.

Financial Disclosure: No financial support was received.

\section{REFERENCES}

1. Davidson, J. K. Clinical diabetes mellitus, diabetic eye disease. Thime Medical Publishers 1991;427-444

2. Murakami T. Yoshimura N. Structural changes in individual retinal layers in diabetic macular edema. J Diabetes Res. 2013;920713.

3. Aiello, L.P. Angiogenic pathways in diabetic retinopathy. N Eng J Med. 2005;353:839-41.

4. Antonetti D.A., Barber A.J., Khin S. et al. Vascular permeability in experimental diabetes is associated with reduced endothelial occludin content: vascular endothelial growth factor decreases occludin in retinal endothelial cells. PennState Retina Research Group. Diabetes. 1998;47:1953-9.

5. Nguyen QD, Shah SM, Khwaja AA, et al. READ-2 Study Group. Two-year outcomes of the ranibizumab for edema of the macula in diabetes (READ-2) study. Ophthalmology. 2010;117:2146-51.

6. Soheilian M., Ramezani A., Obudi A., et al. Randomized trial of intravitreal bevacizumab alone or combined with triamcinolone versus macular photocoagulation in diabetic macular edema. Ophthalmology 2009;116:1142-50.

7. Ferrara N., Domico L., Shams N, et al. Development of ranibizumab, an anti-vascular endothelial growth factor antigen binding fragment, as therapy for neovascular agerelated macular degeneration. Retina. 2006; 26:859-70.

8. Photocoagulation for diabetic macular edema. Early Treatment Diabetic Retinopathy Study report number 1. Early Treatment Diabetic Retinopathy Study research group. Arch Ophthalmol. 1985;103:1796-1806. 
9. Yang JC, Haworth L, Sherry RM, et al. A randomized trial of bevacizumab, an anti-vascular endothelial growth factor antibody, for metastatic renal cancer. N Engl J Med. 2003;349:427-34.

10. Marshall J. The role of bevacizumab as first-line therapy for colon cancer. Semin Oncol. 2005;32:S43-S47.

11. Michels S, Rosenfeld PJ, Puliafito CA, et al. Systemic bevacizumab (Avastin) therapy for neovascular age-related macular degeneration: twelve-week results of an uncontrolled open-label clinical study. Ophthalmology. 2005; 112:1035-47.

12. Rosenfeld PJ, Moshfeghi AA, Puliafito CA. Optical coherence tomography findings after an intravitreal injection of bevacizumab (Avastin) for neovascular age-related macular degeneration. Ophthalmic Surg Lasers Imaging. 2005;36:331-5

13. Avery RL, Pieramici DJ, Rabena MD, et al. Intravitreal bevacizumab (Avastin) for neovascular age-related macular degeneration. Ophthalmology. 2006;113:363-72.

14. Rosenfeld PJ, Fung AE, Puliafito CA. Optical coherence tomography findings after an intravitreal injection of bevacizumab (Avastin) for macular edema from central retinal vein occlusion. Ophthalmic Surg Lasers Imaging. 2005;36:336-9.

15. Massin P, Bandello F, Garweg JG, et al. Safety and efficacy of ranibizumab in diabetic macular edema (RESOLVE Study): a 12-month, randomized, controlled, double-masked, multi- centerphase II study. Diabetes Care. 2010;33:2399-405.

16. Turkoglu EB, Celık E, Aksoy N, et al. Changes in vision related quality of life in patients with diabetic macular edema: Ranibizumab or laser treatment? J Diabetes Complications. 2015;29:540-43.
17. Brown DM, Nguyen QD, Marcus DM, et al. Long-term outcomes of ranibizumab therapy for diabetic macular edema: The 36-month results from two phase III trials: RISE and RIDE. Ophthalmology 2013;120:2013-2022.

18. Vaze A, Fraser-Bell S, Gillies M.anagha. Reasons for discontinuation of intravitreal vascular endothelial growth factor inhibitors in neovascular age-related macular degeneration. Retina. 2014; 34:1774-8.

19. Muether P., Droege K.M., Fause S. Vascular endothelial growth factor suppression times in patients with diabetic macular oedema treated with ranibizumab. Br J Ophthalmol. 2014; 98:179-81.

20. Ikemori S, Kato A, Yasukawa T, et al. Effect of a singledose regimen of intravitreal ranibizumab in the treatment of neovascular age-related macular degeneration. J Clin Exp Ophthalmol. 2012;3:221.

21. Han XX, Guo CM, Li Y, Hui YN. Effects of bevacizumab on the neovascular membrane of proliferative diabetic retinopathy: reduction of endothelial cells and expressions of VEGF and HIF-1 $\alpha$. Mol Vis. 2012;18:1-9

22. Yoon D, Rusu I, Barbazetto I. Reduced effect of anti-vascular endothelial growth factor agents on diabetics with vitreomacular interface abnormalities. Int Ophthalmol. 2014; $34: 817-23$.

23. Elman M.J., Aiello L.P., Beck R.W. et al. Randomized trial evaluating ranibizumab plus prompt or deferred laser or triamcinolone plus prompt laser for diabetic macular edema. Ophthalmology. 2010;117:1064-77.

24. Selen F., Demirel S., Batıglu F., Özmert E. Factors associated with visual acuity after treatment of diabetic macular edema with intravitreal ranibizumab. Retina-Vitreus. 2013;21:269-73. 